Acta vet. scand. $1971,12,513-522$.

From the Department of Microbiology and Immunology, Veterinary College of Norway, Oslo.

\title{
IDENTIFICATION OF CRUDE AND PURIFIED BACTERIAL PROTEINASES BY AGAR GEL DIFFUSION AND AGAR GEL ELECTROPHORETIC PROCEDURES
}

\author{
By \\ Hans Kolbein Dahle
}

Many applications of the double diffusion technique have been developed since its introduction by Ouchterlony in 1949 (Crowle 1961, Ouchterlony 1969). The method has also been used in the study of enzyme-antienzyme systems (Arnon \& Perlmann 1963, Halbert 1963, Uriel 1963) and toxin-antitoxin systems (Raynaud \& Relyveld 1959, Skulberg 1964). However, when used in this type of investigation, the technique requires antigens of high purity, or, if more appropriate, sera absorbed for a high degree of specificity. The resolving power of the procedure has been increased considerably by immunoelectrophoresis.

The enzymoserological principle of the casein precipitation inhibition test (CPI-test) (Dahle $1969 \mathrm{~b}$ ) has been utilized for studies of various microbial proteinases (Sandvik 1962, 1967, 1969, Rutqvist 1969, Fossum 1970). After electrophoretic separation of the induced antiproteinases from the normal proteinase inhibitors in immune rabbit sera the antiproteolytic effect of the $\gamma$-globulins can be demonstrated by their ability to inhibit the corresponding enzymes from precipitating sodium caseinate in an agar gel.

A zymogram technique has been developed (Dahle 1970) for analysing the complexity of enzymes in proteinase mixtures. By this method, which is based on the electrophoretic separation 
of the proteinases in agar gel, and subsequent development with a sodium caseinate-containing covering gel, the different proteinases can be localized.

The relationships between the proteinases formed by Aeromonas liquefaciens (enzymes A and B) and Ae. salmonicida (enzyme B) and their corresponding antiproteinases (Dahle $1969 \mathrm{~b}$ ), are considered to be suitable systems for studying the specificity and sensitivity of various identification reactions for proteinases. The present work deals with comparative studies of agar diffusional and agar electrophoretic procedures for the identification of bacterial proteinases in crude and purified states, and the application of the methods in confirming the relationships between the Aeromonas proteinases previously described (Dahle $1969 \mathrm{~b}, 1970$ ).

\section{MATERIALS AND METHODS}

Enzymes. Proteinase-antigens were produced by growing Aeromonas liquefaciens ( $\mathrm{ATCC}^{\star}$ 14715), Aeromonas salmonicida (ATCC 14174) and Pseudomonas aeruginosa $\left(\mathrm{NVH}^{\star \star}\right.$ 150) on semi-solid skim milk agar (SMA-antigens) and nutrient gelatin (NG-antigens) as described previously (Dahle $1969 \mathrm{a}, \mathrm{b}$ ). The SMA-cultures of Ae. liquefaciens contained both the proteinases $A$ and $B$, while the NG-cultures contained only the proteinase $B$, which is also produced by Ae. salmonicida in these media. The proteinase A produced by Ae. liquefaciens was purified from the Ae. liquefaciens SMA-cultures, and the proteinase B from Ae. salmonicida SMA-cultures. The purification procedure includes precipitation with ammonium sulphate, batchwise treatment with DEAE-cellulose and gel filtration on Sephadex G-100 (Dahle 1971).

Sera. Antiproteinases against the SMA-antigens, NG-antigens and the purified proteinase $B$ were produced in rabbits as described previously (Dahle 1969 a). The sera were termed SMAantisera, NG-antisera and B-antiserum.

Agar diffusion and agar electrophoresis. The double diffusion technique and the immunoelectrophoresis were carried out in $1 \%$

* American Type Culture Collection, Rockville, Maryland, USA.

* * The Culture Collection at the Department of Microbiology and Immunology, Veterinary College of Norway, Oslo. 
agar (Difco*, special noble-agar, 0142-01) in $0.05 \mathrm{M}$ phosphate buffer, $\mathrm{pH}$ 6.2. Agar gels were poured on microscope slides (LKB ${ }^{\star \star}$-equipment for immunoelectrophoresis) and the electrophoresis run for $60 \mathrm{~min}$. at $300 \mathrm{v}$ with $0.05 \mathrm{M}$ phosphate buffer, pH 6.2, as electrode buffer. Zymograms of the proteinases were prepared as described by Dahle (1970), in which the agar gels, buffers and electrophoretic conditions were identical with those of the immunoelectrophoresis. Serological differentiations according to the principle of the CPI-test were carried out as described (Dahle $1969 \mathrm{~b}$ ). The CPI-test is based on the separation of the antiproteinases in immune sera from normal proteinase inhibitors by paper electrophoresis, followed by demonstration of inhibition of the casein precipitation reaction in the area of the antiproteinases.

Comparison of the sensitivities of the double diffusion technique and the CPI-test. Antigens and antisera were diluted 1:2, $1: 4,1: 6,1: 8, \ldots \ldots, 1: 40$, and the antigens also $1: 100,1: 200$, $1: 400,1: 600,1: 800, \ldots \ldots, \ldots, 1: 2000$ in saline. The double diffusion technique and the CPI-test were compared using serial dilutions of the antigens and the antisera. Each dilution of the antiserum was tested crosswise against all the dilutions of the antigens in order to avoid disproportions between the components. The highest dilutions of antigens giving positive reactions by the double diffusion technique ( $1 / \mathrm{a})$, and by the CPI-test $(1 / \mathrm{c})$, were taken as endpoints. Similarly, the highest dilutions of the antisera $(1 / \mathrm{b}$ and $1 / \mathrm{d})$ giving positive reactions by the two methods, were taken as endpoints for the antisera. The relationships between the sensitivities of the methods were expressed by the quotients $c / a$ and $d / b$ for the antigens and antisera respectively (Table 1).

\section{RESULTS}

Crude preparations of enzymes (SMA-proteinases and NGproteinases) produced by Ae. liquefaciens, Ae. salmonicida and Ps. aeruginosa were tested against SMA-antisera by the double diffusion technique, and by immunoelectrophoresis of the antigens (Figs. $1 \mathrm{a}, \mathrm{b}, \mathrm{c}, \mathrm{d}$ ). The number of precipitation lines ob-

* Difco Laboratories Inc., Michigan, USA.

* * LKB Instruments Ltd., Stockholm-Bromma, Sweden. 

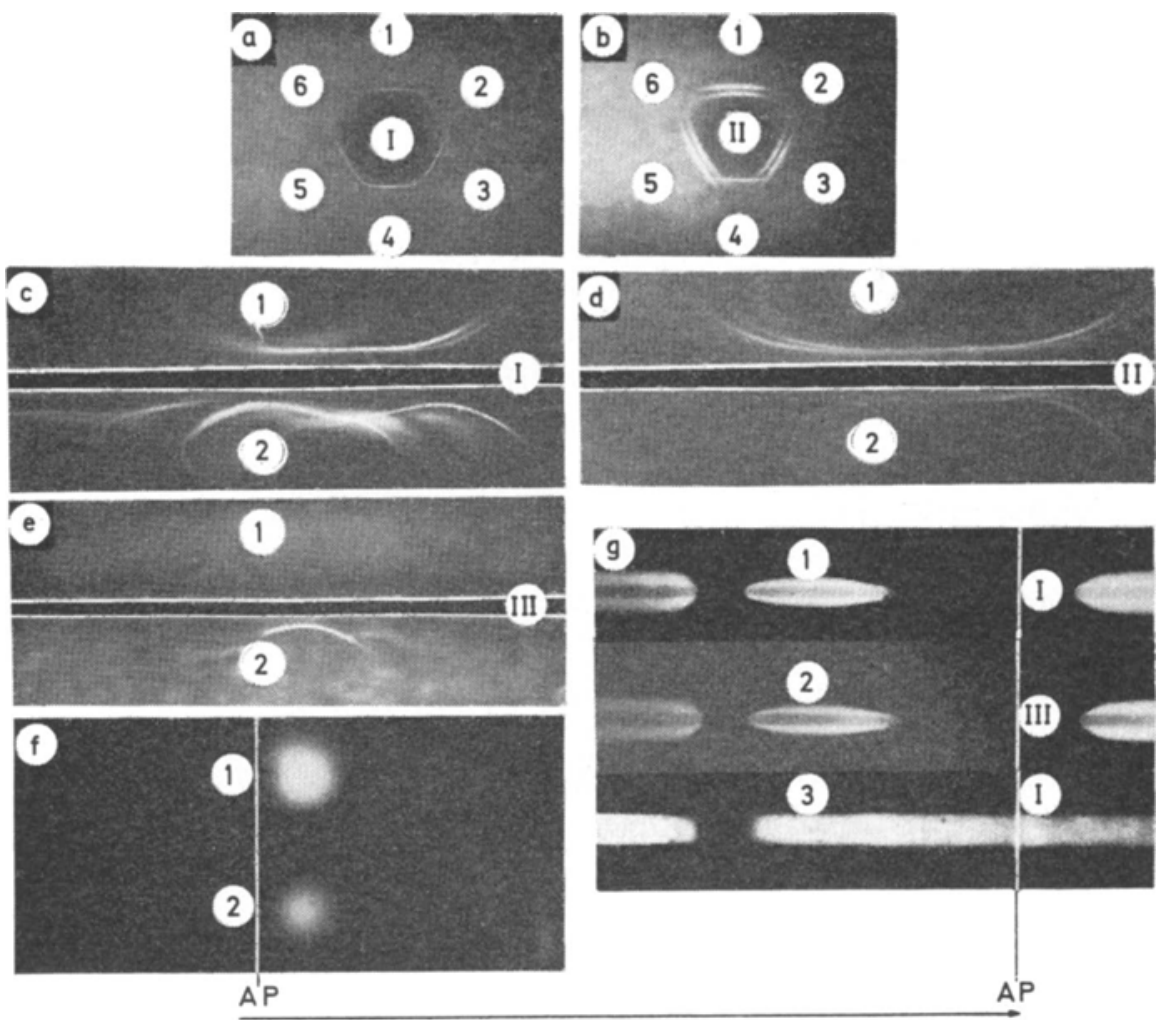

Fig u r e 1. The double diffusion technique without (a, b), and with $(c, d, e)$, electrophoretic separation of the antigens prior to the diffusion, the agar gel zymogram technique (f), and the casein precipitation inhibition test (g) employed for studies on bacterial proteinases before and after purification.

a: Crude proteinase-antiproteinase system. I: Ae. salmonicida SMAantiserum; 1, 3, 4 and 5: Ae. salmonicida SMA-antigens; 2. Ae. liquefaciens SMA-antigens; 6 : Pseudomonas aeruginosa SMA-antigens.

b: Crude proteinase-antiproteinase system. II: Ae. liquefaciens SMAantiserum; 1, 3 and 5: Ae. liquefaciens SMA-antigens; 2 and 6: Ae. liquefaciens NG-antigens; 4: Ae. salmonicida SMA-antigens.

c: Crude proteinase-antiproteinase system. I: Ae. salmonicida SMAantiserum. 1: Ae. liquefaciens SMA-antigens; 2: Ae. salmonicida SMA-antigens.

d: Crude proteinase-antiproteinase system. II: Ae. liquefaciens SMAantiserum; 1: Ae. liquefaciens SMA-antigens; 2: Ae. salmonicida SMA-antigens.

e: Purified proteinase-antiproteinase system. III: B-antiserum; 1 : proteinase A, 2: proteinase B.

f: Zymograms of 1: Ae. salmonicida SMA-proteinase and 2: the purified proteinase B. AP: the line of application.

g: Electrophoretic patterns of the CPI-test. I: Ae. salmonicida SMAantiserum developed with 1: Ae. salmonicida SMA-proteinase; II: B-antiserum developed with the purified proteinase B (2). As a negative control, the Ae. salmonicida SMA-antiserum (I) was also developed with Ps. aeruginosa SMA-proteinase (3). The specific antibodies are localized in the area of the line of application (AP), and the normal serum inhibitors can be seen to the left of this line. The cathodic direction is marked with an arrow. 
served, varied from batch to batch, and even during storage as was shown when one batch was examined before and after storage at $4^{\circ} \mathrm{C}$. The figures also indicate the occurrence of crosswise precipitation between the antigen-antibody systems (SMA) of Ae. liquefaciens and Ae. salmonicida. Between the Ae. liquefaciens NG-antigens and the Ae. salmonicida SMA-antigens containing enzymoserologically identical proteinases (Dahle $1969 \mathrm{~b}$ ), spurs were observed (Fig. 1 a) indicating partial identity. However, the relationships between the heterologous reactions were obscure, and no precipitation line could be identified as being due to a particular proteinase-antiproteinase reaction.

After purification of proteinase $B$, the number of precipitation lines with the corresponding B-antiserum was reduced to one (Fig. $1 \mathrm{e}$ ). The same result was obtained when testing proteinase $B$ against Ae. salmonicida SMA-antiserum. The purified proteinase A prepared from Ae. liquefaciens SMA-cultures caused only one line when tested against Ae. liquefaciens SMA-antiserum. No precipitation line occurred between the purified proteinase $A$ and the B-antiserum, nor between the purified proteinase $B$ and the Ae. liquefaciens SMA-antiserum. Using Ae. salmonicida SMAantigens stored for several months at $4^{\circ} \mathrm{C}$, the immunoelectrophoretic picture was similar to that of the purified proteinase $B$ (Fig. $1 \mathrm{e}$ ). Only one precipitation line appeared when this crude enzyme solution was tested against Ae. salmonicida SMA-antiserum and antiserum against purified proteinase $B$.

The zymograms (Fig. $1 \mathrm{f}$ ) indicate an identical localization of the proteinase of the Ae. salmonicida SMA-culture and the purified proteinase $B$, when the electrophoresis was carried out under the same conditions as those of the immunoelectrophoresis shown in Figs. $1 c_{k} d$, and e. It should be emphasized that the localization of the precipitation line in Fig. 1 e corresponds to the casein precipitation spots in Fig. $1 \mathrm{f}$.

Fig. $1 \mathrm{~g}$ shows the electrophoretic pattern of the proteinaseantiproteinase system of Ae. salmonicida in the crude and purified states, tested by the CPI-test. Proteinases (1 and 2) homologous to the antiproteinases in the sera were inhibited characteristically in their precipitation of sodium caseinate in the area of the antiproteinases ( $\gamma$-globulins), while heterologous proteinases (3) were not affected at all in that area.

In Table 1, the relationships between the sensitivities of the double diffusion technique and the CPI-test are calculated for 
T a b l e 1. Comparison of the sensitivities ${ }^{\star}$ of the reactions based on the double diffusion-technique (DD-t) and the casein precipitation inhibition test (CPI-t) in homologous systems.

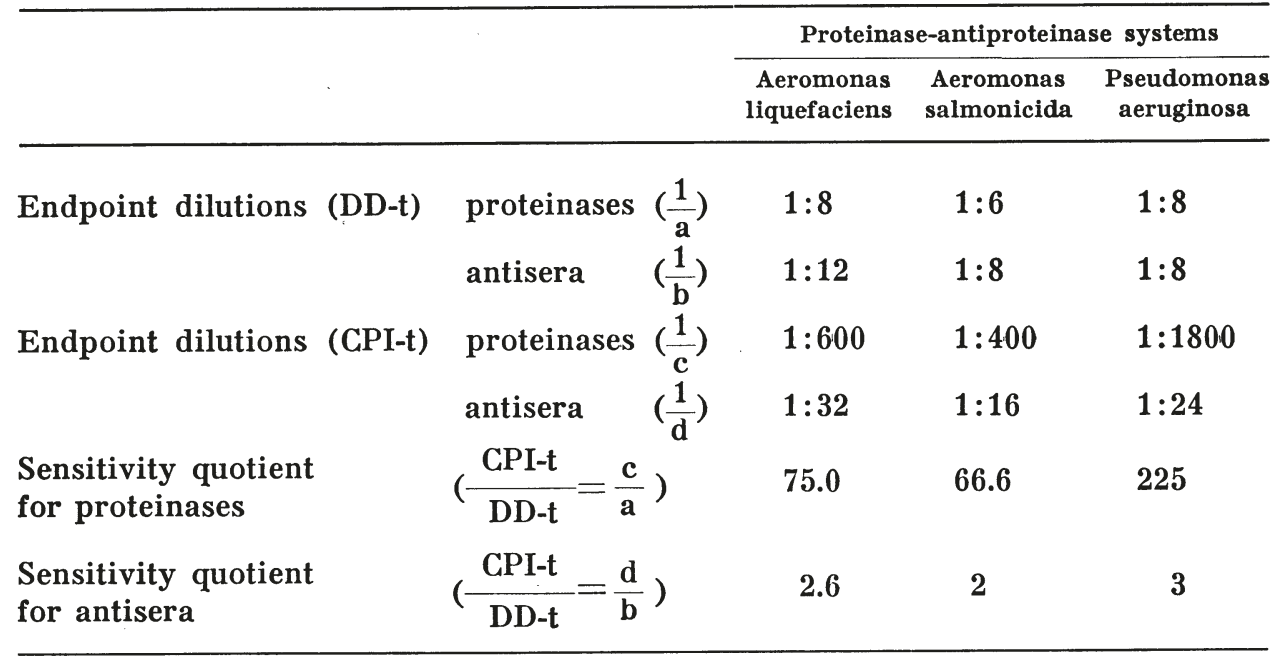

* Sensitivity is defined as the inverse value of the denominator for endpoint dilutions.

both antigens and antisera. The table shows that the CPI-test was 66 to 225 times more sensitive than the double diffusion technique with respect to the proteinases, and two to three times more sensitive with respect to antisera, for the three systems examined.

\section{DISCUSSION}

At present, no reliable biochemical criteria exist for the identification of various proteinases, although quantitative assays have been performed in a number of ways, using casein as substrate (Kunitz 1947, Sandvik 1962, Dahle 1969 a). Therefore, techniques for identifying enzymes by serological methods are of particular interest. In this connection, attention should be drawn to the papers presented by Sandvik (1962, 1967, 1969).

In the present work, a variety of precipitation lines occurred in immunodiffusion and immunoelectrophoresis of the crude proteinase solutions and their corresponding antisera. The precipitation lines and the spurs support the previous findings regarding Aeromonas proteinases (Dahle $1969 \mathrm{~b}, 1970$ ) although the reactions do not seem to be sufficiently specific for detailed analysis of the relationships between the proteinases in question. 
These observations are therefore of minor interest with respect to the enzyme-antienzyme reactions, because of the difficulties in identifying the precipitation lines caused by enzyme antigens. However, the reactions may be made specific if the antigens are purified, or the antisera are absorbed for unspecific compounds. Thus, the purified enzyme B caused one single precipitation line with antiserum against crude SMA-antigens. On the other hand, it was confusing that the crude proteinase solution gave the same pattern as the purified proteinase after storage for several months in a refrigerator. The explanation of this phenomenon is probably that the proteinase, during the storage period, caused a digestion of the protein components in the solution while the antigenicity of the proteinase itself was left intact. This observation may be a warning against the often optimistic and uncritical consideration of immunoelectrophoretic singularity as a criterion of success in purification procedure with biological components.

The zymograms (Fig. $1 \mathrm{f}$ ) show similar pictures for the crude and purified proteinase B. This method is mainly of importance for determining the number of proteinases present in the solution, and for localizing the enzymes after an electrophoresis run (Dahle 1970). In addition, the zymograms can, in combination with the immunoelectrophoretic patterns of the double diffusion technique, sometimes give information about which of the precipitation lines represents the proteinase-antiproteinase system. Thus, it can be seen that the one line in Fig. 1 e, and only one line in Fig. $1 \mathrm{c}$ correspond with the localization of the proteinase in the zymogram (Fig. $1 \mathrm{f}$ ), while all the other lines in Fig. $1 \mathrm{c}$ are without significance for the proteinase reactions.

The serological identification of proteinases based on the CPItest (Fig. $1 \mathrm{~g}$ ) is, on the other hand, reliable, and obviously very specific, also when crude, unpurified, enzyme-containing material is used, due to the biocatalytical effect of the antigens being specifically inhibited by the sera. None of the other antigenic components in the crude proleinase solution seem to interfere with the test, as the proteinases are the only fractions capable of precipitating sodium caseinate in the agar gel under the conditions used. The specificity of the CPI-test is therefore independent of purification of the enzymes when only one proteinase is present in the material (Fig. $1 \mathrm{~g}$ ). This makes the CPI-test a most valuable procedure for identifying specific bacterial proteinases, but limits its use as a criterion of purity after purification steps. The method 
requires, however, that a proper substrate is incorporated in the agar gel.

For comparing sensitivity values, the endpoint reactions of the double diffusion technique were determined as the highest dilution of antigens causing any precipitation lines, ignoring whether the lines were due to the proteinases, or any other antigenic components in the enzyme-containing solution. This means that the sensitivities of the methods were interpreted in the, theoretically, most favourable way for the double diffusion technique. The sensitivity quotients (Table 1) should be considered, therefore, as minimum values. It should be emphasized in this connection that the double diffusion technique and the CPI-test are based on quite different principles, as the latter, in contrast to the double diffusion technique, directly involves the biocatalytical effect of the enzymes in question. Thus, the antienzymes reacted as biological inhibitors and precipitating agents, respectively. It is important that the term antienzyme (antiproteinase) should be taken to mean serum inhibitors, of $\gamma$-globulin nature, specifically inhibiting the biological activity of the enzymes (proteinases). A corresponding specificity between enzyme and antienzyme may not be the case for other serological reactions such as precipitation or agglutination.

The greater sensitivity of the CPI-test as compared with that of the double diffusion technique seems to indicate that the ratio between biocatalytical effect and the amount of enzyme protein present is extremely high for this type of enzyme. This fact should be considered when using the double diffusion technique as a test for purity of biocatalytically active proteins, as a high functional activity may be present in an enzyme solution, although the content of enzyme protein is too small to allow the development of any precipitation lines. This may be the explanation of the failing reaction between purified proteinase $B$ and Ae. liquefaciens SMA-antiserum.

\section{REFERENCES}

Arnon, R. \& G. E. Perlmann: Antibodies to pepsinogen and pepsinogen modifications. Ann. N.Y. Acad. Sci. 1963, 103, 744-750.

Crowle, A. J.: Immunodiffusion. Academic Press, New York and London 1961, $333 \mathrm{pp}$.

Dahle, $H$. K.: Quantitative assay of a single proteolytic enzyme in a crude mixture of bacterial proteinases. Acta path. microbiol. scand, 1969 a, 77, 134-142. 
Dahle, H. K.: Enzymoserological separation of bacterial proteinases. Acta path. microbiol. scand. $1969 \mathrm{~b}, 77,143-148$.

Dahle, H. K.: Zymograms in agar gel of some animal and bacterial proteinases. Acta path. microbiol. scand. 1970, Section B, 78, 575580.

Dahle, H. K.: Purification and some properties of two Aeromonas proteinases. Acta path. microbiol. scand. 1971, Section B, 79. In press.

Fossum, K.: Proteolytic enzymes and biological inhibitors II. Naturally occurring inhibitors in sera from different species and their effect upon proteolytic enzymes of various origin. Acta path. microbiol. scand. 1970, Section B, 78, 605-618.

Halbert, S. P.: Naturally occurring human antibodies to streptococcal enzymes. Ann. N.Y. Acad. Sci. 1963, 103, 1027-1048.

Kunitz, M.: Crystalline soybean trypsin inhibitor. II. General properties. J. gen. Physiol. 1947, 30, 291-310.

Ouchterlony, $\emptyset$.: Handbook of Immunodiffusion and Immunoelectrophoresis. Ann Arbor Science Publishers, Inc., Ann Arbor 1969, $215 \mathrm{pp}$.

Raynaud, M.\&E. Relyveld: La reaction toxine-antitoxine diphteriques. (The toxine-antitoxine reaction of diphteria). Ann. Inst. Pasteur $1959,97,636-678$.

Rutqvist, L.: Studies on Aspergillus fumigatus; properties of intracellular proteinase. Acta vet. scand. 1969, 10, 234-254.

Sandvik, O.: Studies on Casein Precipitating Enzymes of Aerobic and Facultatively Anaerobic Bacteria. Thesis. Veterinary College of Norway, Oslo 1962.

Sandvik, O.: Identification of moulds by serologic differentiation of their proteolytic enzymes. Acta path. microbiol. scand. 1967, 71, 333-338.

Sandvik, O.: Enzymo-serological comparison of proteolytic enzymes produced by Salmonella species and other enterobacteria. Acta vet. scand. 1969, 10, 225-233.

Skulberg, A.: Studies on Formation of Toxin by Clostridium Botulinum. Thesis. Veterinary College of Norway, Oslo 1964.

Uriel, J.: Characterization of enzymes in specific immuneprecipitates. Ann. N.Y. Acad. Sci. 1963, 103, 956-979.

\section{SUMMARY}

The double diffusion technique, immunoelectrophoresis, the zymogram technique for proteinases and the casein precipitation inhibition test (CPI-test) were employed for identification of specific bacterial proteinases produced by Aeromonas liquefaciens, Aeromonas salmonicida and Pseudomonas aeruginosa. The precipitation lines observed with both homologous and heterologous proteinase-antiproteinase systems in the double diffusion technique and in immunoelectrophoresis, supported in certain respects previous findings regarding the Aeromonas proteinases, but the reactions were not sufficiently specific to give a confirmation of the real relationships between the protein- 
ases. It is concluded that the double diffusion technique and immunoelectrophoresis are less specific than the CPI-test for the identification of both crude, and purified, proteinase-antiproteinase systems. The zymograms, in combination with the immunoelectrophoretic patterns, could under certain conditions give useful information about the identity of lines representing the proteinase-antiproteinase precipitates in the double diffusion systems. The number of precipitation lines caused by the crude proteinase solutions in immunoelectrophoresis decreased during storage of the crude antigens, and the solutions could finally behave like the solution of purified antigen.

It was shown that the CPI-test was at least 66 to 225 times more sensitive with respect to antigens, and two to three times more sensitive with respect to antisera than the double diffusion technique, for the three systems examined. This is of methodological importance, as high functional activity may be present in a proteinase solution although the structural conditions are unsuitable or the amount of enzyme protein is too small to allow the development of any precipitation lines in the double diffusion technique.

\section{SAMMENDRAG}

Identifikasjon av urensede og rensede bakterielle proteinaser ved hjelp av agardiffusjons- og agarelektroforetiske metoder.

Dobbeldiffusjonsteknikken, immunoelektroforese, zymogramteknikken for proteinaser og kaseinpresipitasjons-inhibisjonstesten (CPItesten) ble anvendt for identifikasjon av spesifikke bakterielle proteinaser produsert av Aeromonas liquefaciens, Aeromonas salmonicida og Pseudomonas aeruginosa. Presipitasjonslinjene som ble observert både med homologe og heterologe proteinase-antiproteinasesystemer ved dobbeldiffusjonsteknikken og immunoelektroforese, underst $\varnothing$ ttet $i$ visse henseender de tidligere funn med hensyn til Aeromonasproteinasene, men reaksjonene var ikke tilstrekkelig spesifikke til å stadfeste de virkelige relasjonene mellom proteinasene. Det ble konkludert med at dobbeldiffusjonsteknikken og immunoelektroforese er mindre spesifikke enn CPI-testen for identifikasjon av både urensede og rensede proteinase-antiproteinasesystemer. Zymogrammene kunne under visse omstendigheter gi verdifulle opplysninger om identiteten til linjer som representerte proteinase-antiproteinase-presipitater i dobbeldiffusjonsystemene, når de ble brukt i kombinasjon med de immunoelektroforetiske mønstre. Antallet av presipitasjonslinjer forårsaket av de urensede proteinasel $\varnothing$ sningene ved immunoelektroforese, avtok ved lagring av de urensede antigenene, og løsningene oppførte seg til slutt som løsningen av det rensede antigen.

Det ble vist at CPI-testen var minst 66 til 225 ganger mer sensitiv med hensyn til antigenene, og to til tre ganger mer sensitiv med hensyn til antisera enn dobbeldiffusjonsteknikken for de tre systemene som ble unders $\varnothing \mathrm{kt}$. Dette er av metodologisk betydning, da høy funksjonell aktivitet kan være til stede $i$ en proteinasel $\varnothing$ sning selv om de strukturelle betingelser ikke er passende eller mengden av enzymprotein er for liten til å forårsake noen presipitasjonslinjer ved dobbeldiffusjonsteknikken.

(Received October 21, 1970). 